\title{
Unusual variability of penis shape in a leafhopper Acia olivacea (Anufriev, 1969) (Homoptera: Auchenorrhyncha: Cicadellidae: Typhlocybinae)
}

\author{
Необычная изменчивость формы пениса у џикадки \\ Acia olivacea (Anufriev, 1969) \\ (Homoptera: Auchenorrhyncha: Cicadellidae: Typhlocybinae)
}

\author{
D.Yu. Tishechkin \\ A.Ю. Тишечкин
}

Department of Entomology, Faculty of Biology, M.V. Lomonosov Moscow State University, Vorobyevy Gory, Moscow 119234, Russia. Email: macropsis@yandex.ru

Кафедра энтомологии Биологического факультета Московского государственного университета им. М.В. Ломоносова, Воробьёвы Горы, Москва 119234, Россия.

KEY WORDS: leafhoppers, Auchenorrhyncha, Cicadellidae, Typhlocybinae, variability, morphology, genitalia.

КЛЮЧЕВЫЕ СЛОВА: цикадовые, Auchenorrhyncha, Cicadellidae, Typhlocybinae, изменчивость, морфология, гениталии.

ABSTRACT. In Acia olivacea (Anufriev, 1969) more rare form with side appendages on penis and abundant form without appendages are described. Both forms were found in the same population, intermediate variants of penis shape are very rare. No signs of parasitoid invasion in any of these forms were found.

РЕЗЮМЕ. У Acia olivacea (Anufriev, 1969) описаны две формы: более редкая - с боковыми отростками на пенисе и более обычная - без отростков. Обе формы обнаружены в одной популяции, промежуточные варианты между ними крайне редки. Признаков заражения паразитоидами ни у одной из форм не выявлено.

\section{Introduction}

In small Auchenorrhyncha (Homoptera), species diagnostics for the most part is based on the traits of inner abdominal structures, mainly male genitalia. Quite often species indistinguishable in external appearance differ clearly from each other in the shape of genital structures or the $2^{\text {nd }}$ abdominal apodemes. For this reason, since about a middle of the XX century in leafhopper taxonomy the shape of male genitalia became a kind of "species ID". Sometimes differences in their morphology even between closely related species are so great, that drawings of genitalia and apodemes can be used for species identification without references to the text.

Traditionally, figures give a picture of genitalia of only one specimen. Thus, accidentally or intentionally it is considered as a reference or standard specimen of a given species. Usually this approach is quite correct because interspecific difference many times surpass intraspecific variability. However, intraspecific variability of genitalia in small Auchenorrhyncha does exist, and can greatly hamper species identification.

If the differences between two species are small, even minor variability hinders identification. An example is a group of Central-Asian willow-dwelling Macropsis species (Homoptera: Cicadellidae: Macropsinae) differing from each other in proportions of penis and in small details of the $2^{\text {nd }}$ abdominal apodeme morphology (Figs 1-21) [Tishechkin, 2015]. In contrast to Macropsis, in the genus Reptalus Emeljanov, 1971 (Homoptera: Cixiidae) the shape of penis is very complex. It would seem that this makes species identification much easier. However, variability of a shape and length of penis appendages hampers much distinguishing between real species and intraspecific forms (Figs 22-25) [Emelyanov, Tishechkin, 2012].

In some cases intraspecific differences in genitalia shape in small Auchenorrhyncha is a result of a geographical or ecological variability. This was demonstrated for a number of European leafhopper species [Wagner, 1967; Le Quesne, Woodroffe, 1976; Gnezdilov, 1999]. For instance, variation in Agallia laevis Ribaut, 1935 suggests a cline or stepped cline from South-Eastern to North-Western Europe in the shape of the anal appendages and penis, while Eupteryx stachydearum (Hardy, 1850) shows a North-South cline, and a similar altitudinal cline, in the length and curvature of the apical processes of penis [Le Quesne, Woodroffe, 1976]. On the other hand, in Italy, differences between populations of Diplocolenus abdominalis (Fabricius, 

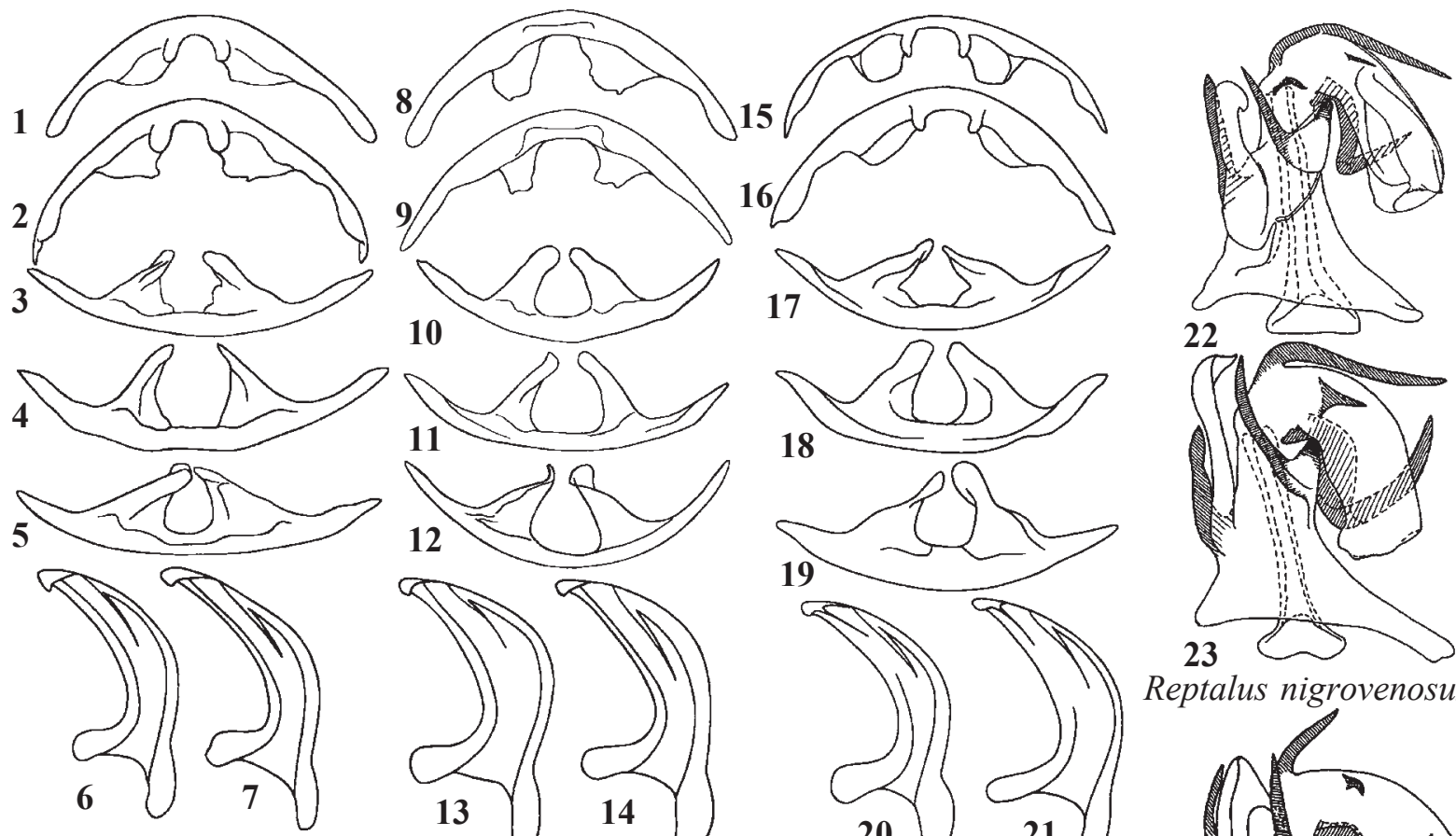

Macropsis tarbagataica
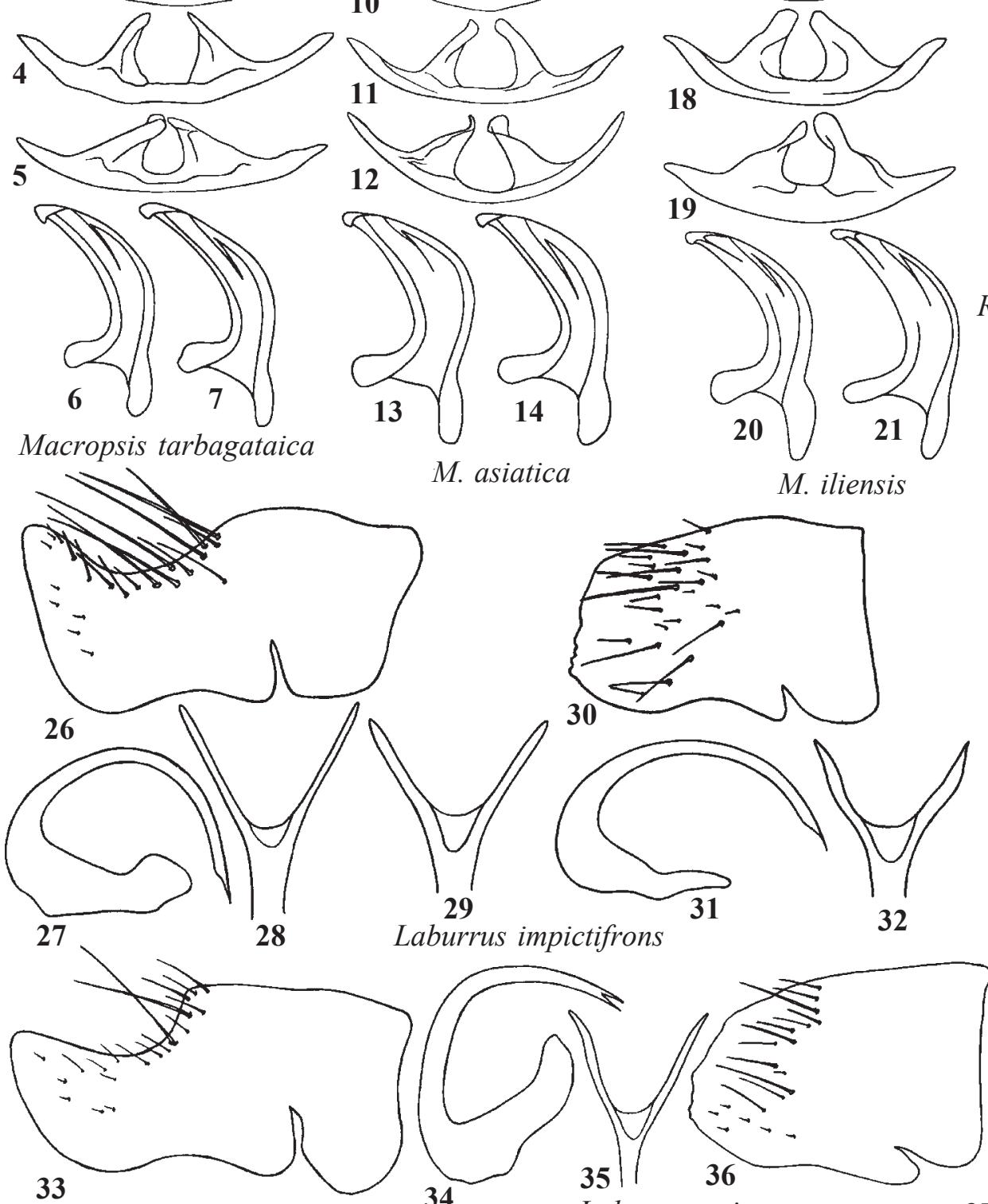

Laburrus impictifrons

32
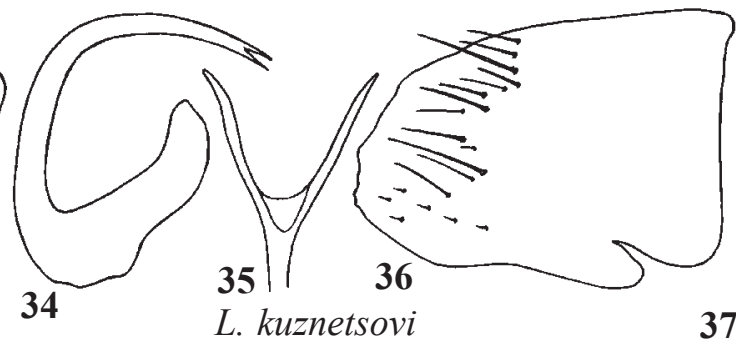

R. narynensis

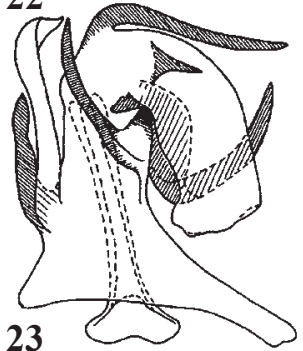

Reptalus nigrovenosus

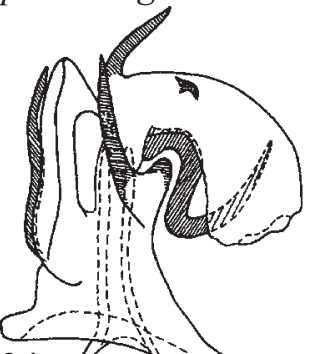

24
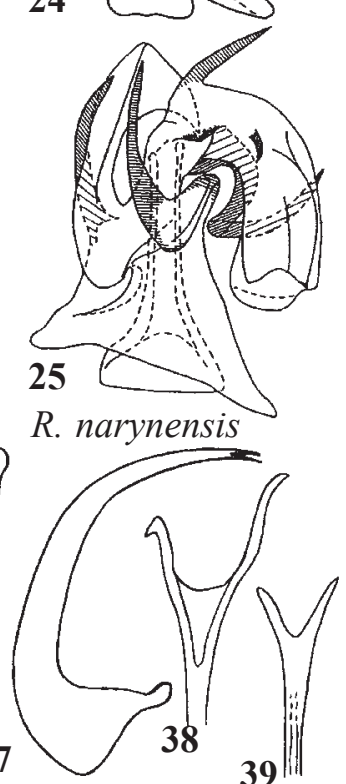

Figs. 1-39. Variability of male genitalia and $2^{\text {nd }}$ abdominal apodemes in leafhoppers: 1-7 - Macropsis tarbagataica Mit.; 8-14 - M. asiatica Dub.; 15-21 - M. iliensis Mit.; 22-23 - Reptalus nigrovenosus Kuzn.; 24-25 - R. narynensis Em. et Tish.; 26-32 - Laburrus impictifrons (Boh.); 33-39 - L. kuznetsovi Em. (26-29 and 33-35 - normal males, 30-32 and 36-39- abnormal males); 1-2, 8-9, 1516 - male abdominal apodemes of $2^{\text {nd }}$ tergite; $3-5,10-12,17-19-$ same of $2^{\text {nd }}$ sternite; $6-7,13-14,20-25,27,31,34,37$ - penis, side view; 26, 30, 33, 36 - pygofer lobe; 28-29, 32, 35, 38-39 - apical part of penis, caudal view; 1-21 — after Tishechkin, 2015; 22-25 after Emeljanov, Tishechkin, 2012; 26-39- after Tishechkin, 2002.

Рис. 1-39. Изменчивость гениталий и аподем II брюшного сегмента самцов цикадок: 1-7 - Macropsis tarbagataica Mit.; 8-14 M. asiatica Dub.; 15-21 - M. iliensis Mit.; 22-23 - Reptalus nigrovenosus Kuzn.; 24-25 - R. narynensis Em. et Tish.; 26-32 - Laburrus impictifrons (Boh.); 33-39 - L. kuznetsovi Em. (26-29 и 33-35 - обычные самцы, 30-32 и 36-39 - самцы с деформированными гениталиями); 1-2, 8-9, 15-16 - аподемы II брюшного тергита самцов; 3-5, 10-12, 17-19 - аподемы II брюшного стернита; 6-7, 13-14, 20-25, 27, 31, 34, 37 - пенис, вид сбоку; 26, 30, 33, 36 - доля пигофора; 28-29, 32, 35, 38-39 - вершина пениса, вид сзади; 1-21 — по: Tishechkin, 2015; 22-25 - по: Emeljanov, Tishechkin, 2012; 26-39 - по Тишечкину, 2002. 
1803) (Homoptera: Cicadellidae: Deltocephalinae) in the length of penis appendages are neither in connection with microclimate nor with the host plant [Olmi, 1976].

A special type of variability is a pathological variability. In leafhoppers, deformation of genitalia often can be caused by parasitic Diptera, Hymenoptera or Strepsiptera. This phenomenon was discovered a long time ago [Giard, 1889] and has since been repeatedly described in the literature [e.g. Ribaut, 1936; Olmi, 1976]. If the deformation is asymmetrical, its parasitic or traumatic origin is obvious. In the case of symmetrical change of genital structures the presence of parasitoids in the abdomen of a leafhopper (e.g. mouthparts of dipteran larvae in preparations macerated in $\mathrm{KOH})$ testify to the parasitic origin of these deformations. In taxonomic works this subject has not received sufficient attention. Only in very few taxonomic papers mutilated specimens are illustrated along with intact ones [e.g. Dworakowska, 1981, 1993].

Another kind of a teratism is intersex specimens. Among the leafhoppers this phenomenon was studied in details in the genus Oncopsis Burmeister, 1838 [Hamilton, 1983]. This abnormality is easy to reveal due to asymmetry of terminalia.

The most difficult case is a variability of genitalia not associated with obvious pathology and occurring within the same population. In this case all organs usually retain symmetry, and there are no signs of parasite invasion; due to this, there is the illusion that several species present in the sample. Examples of overestimation of this kind of variability are so numerous, that there is no need to give references to any particular works. Almost in every taxon there are species with variable morphology or coloration having a long lists of synonymic names. Usually intraspecific differences are the result of a continuous variability, and intermediate forms between two extreme variants can be found. Discrete variability is a much more difficult problem. In this case special investigation of large samples from the same locality or host are necessary to ensure that two different forms always occur together and thus belong to the same species.

Previously, such a phenomenon was discovered in the genus Laburrus Ribaut, 1942 (Homoptera: Cicadellidae: Deltocephalinae) [Tishechkin, 2002]. Apparently, in almost every population, along with usual individuals, a small number of abnormal males occurs (Figs 26-29 and 33-35 - normal males, 30-32 and 36-39abnormal males). These males are indistinguishable in external appearance from normal ones, but have another shape of the pygofer lobes, anal tube, and penis. The genitalia are deformed in the same manner in different species: the posterior margin of the pygofer lobes not elongated and tapering apically (Figs 26 and 33), but widely rounded or nearly straight (Figs 30 and 36); penis bent to a lesser extent (Figs 27, 34 and 31, 37), with apical processes more or less shortened (Figs 28 29, 35 and 32, 38-39); the anal tube is slightly shorter. This phenomenon is, beyond doubt, an aberration, because it is unlikely that a less abundant sibling species exists simultaneously with each usual species of Laburrus, being indistinguishable from it in appearance, but having another shape of the genitalia. In addition, we have never found a sample consisting of such individuals, but including no normal males.

In the present paper polymorphism of male genitalia in Acia olivacea (Anufriev, 1969) (Homoptera: Cicadellidae: Typhlocybinae) is described. Similarly to the genus Laburrus, this variability is discrete and not associated with any obvious pathology.

\section{Material and methods}

Material investigated (all from Russia, collected by the author): Southern Maritime Province, Pogranichny District, env. Barabash-Levada Village (type locality), 14.VII.1995, $1 \sigma^{7}$; Southern Maritime Province, Khasan District, "Kedrovaya Pad" “ ("Cedar Valley") Nature Reserve, env. Primorskiy Village, 9.VIII.2010, $1 \sigma^{\text {? }}$; Amur Area, the right bank of Zeya River about $80 \mathrm{~km} \mathrm{~N}$ of Blagoveshchensk (ca. $2 \mathrm{~km}$ upstream from Natal'ino Village), 27-28.VI.2012, $20 \sigma^{7} \sigma^{7}$ on wet bare soil near the campfire site. All material is deposited in the collection of Zoological Museum of M.V. Lomonosov Moscow State University.

The drawings of genitalia were made from digital photographs of preparations macerated in $\mathrm{KOH}$ and placed into glycerine.

\section{Results and discussion}

Anufriev described Empoasca olivacea, Anufriev, 1969 based on holotype male from Barabash-Levada Village, Pogranichny District, Russian Maritime Province and one female paratype from Suputinsky (presently Ussuriysky) Nature Reserve, Russian Maritime Province [Anufriev, 1969]. Later he established for this species a new genus Ussuriasca [Anufriev, 1972]. Dworakowska [1981] emphasized that Ussuriasca is closely related to the genus Acia. Several years later the synonymy of Ussuriasca under Acia was established and the species under consideration was treated as Acia olivacea [Anufriev, Emelyanov, 1988].

In both monographs on Auchenorrhyncha of the Russian Far East [Anufriev, 1978; Anufriev, Emelyanov, 1988] the drawings of male genitalia of this species from the original description were reproduced. These drawings show S-shaped penis with well-developed lateral processes (Figs 40-41). However, according to Anufriev (personal communication), male holotype has penis without lateral processes, but the drawings for the original description were made from another male from Maritime Province (exact localisation unknown, but, possibly, the same as in holotype). Also, he has dissected two males from Lazovsky Nature Reserve, Southern Maritime Province; both males had penis with lateral processes.

In the course of my fieldwork in the Russian Far East I collected two specimens of $A$. olivacea in the Southern 

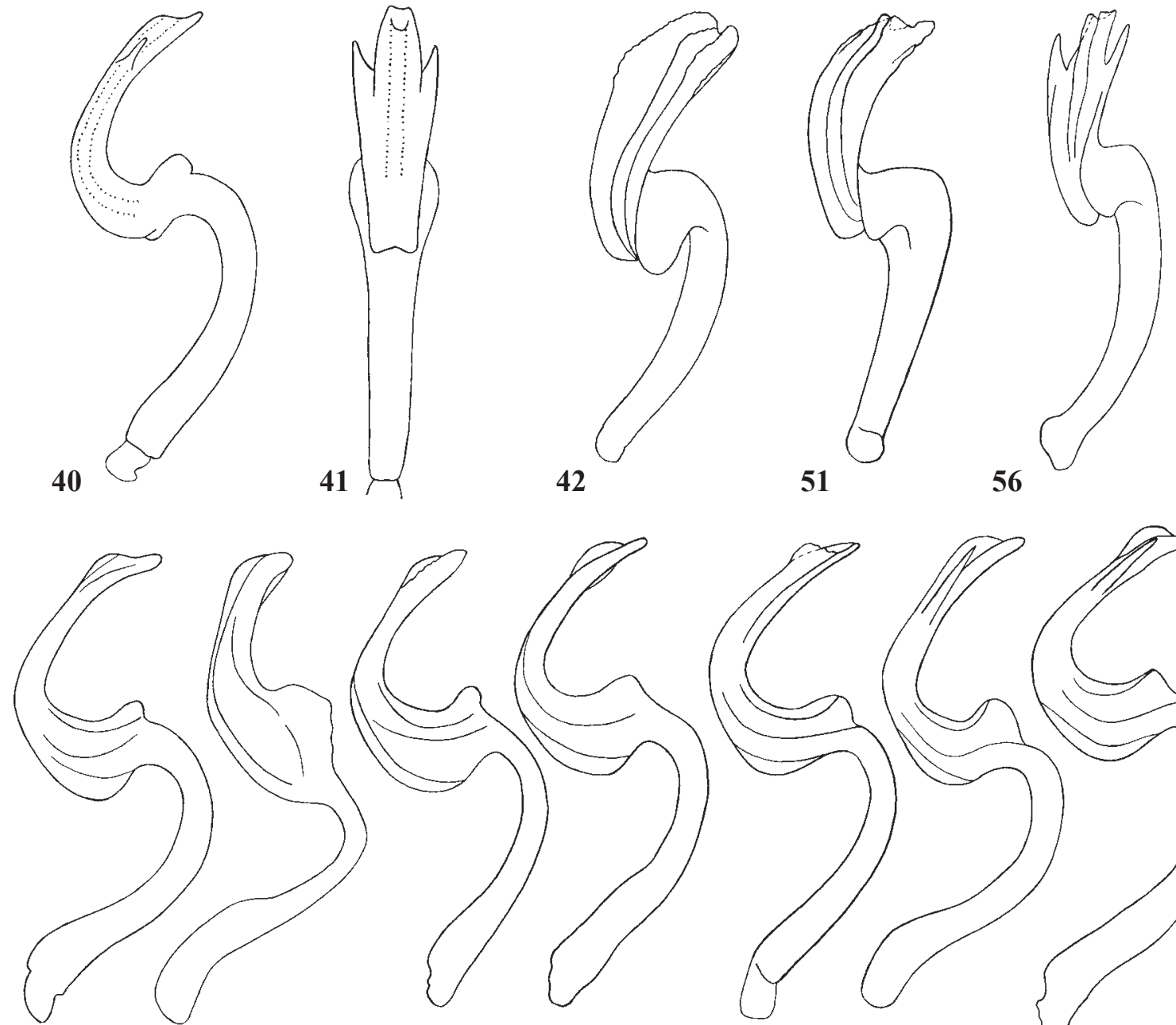

43

45

47

49
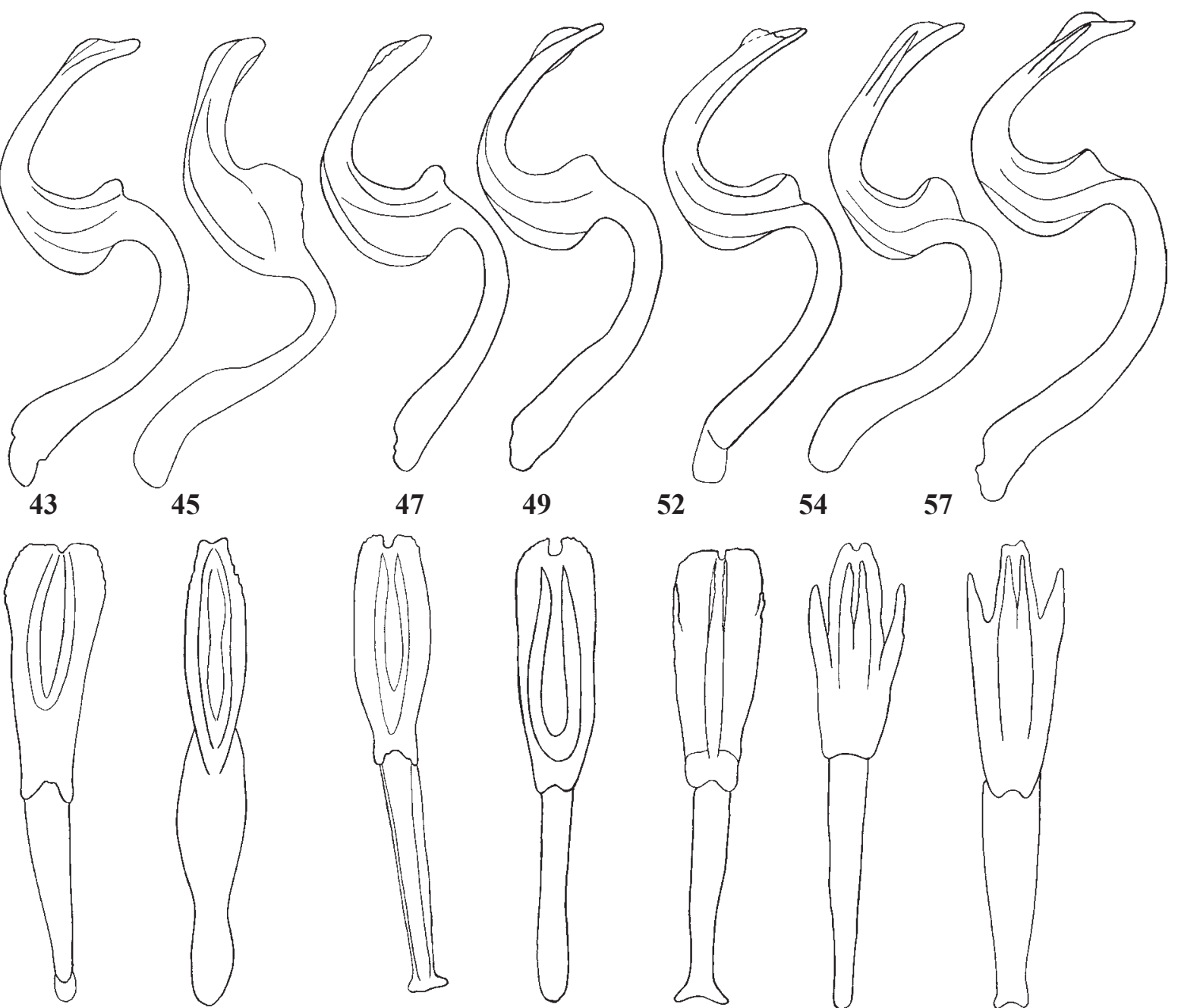

44

46

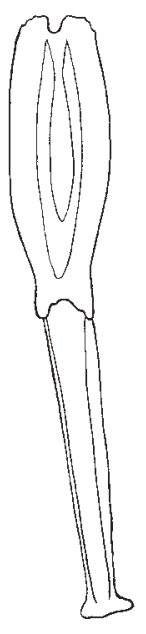

48

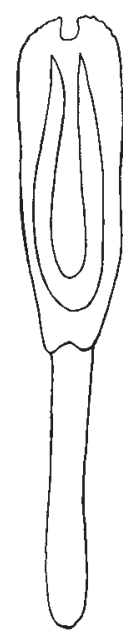

50

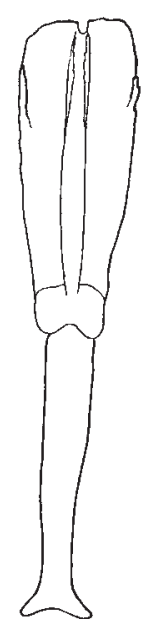

53

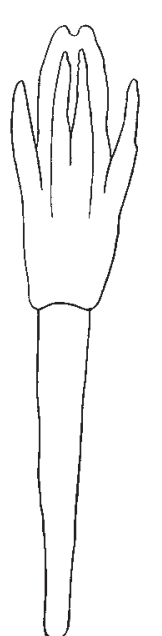

55

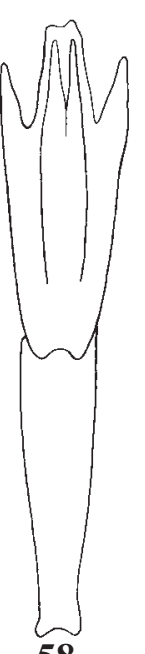

58

Figs 40-58. Variability of penis shape in Acia olivacea: 40, 43, 45, 47, 49, 52, 54, 57 — side view; 41, 44, 46, 48, 50, 53, 55, 58 - caudal view; 42, 51, 56 — caudal-lateral view; 40-41 — after Anufriev, 1978; 42-44 — male from "Kedrovaya Pad' " Nature Reserve; 45-46 — male from the environs of Barabash-Levada Village, Southern Maritime Territory (type locality); 47-58 - five males from Amur Area (47$48,49-50,51-53,54-55$, and 56-58 - penis of the same male in different aspects).

Рис. 40-58. Изменчивость формы пениса у Acia olivacea: 40, 43, 45, 47, 49, 52, 54, 57 — вид сбоку; 41, 44, 46, 48, 50, 53, 55, 58 — вид сзади; 42, 51, 56 - вид сзади-сбоку; 40-41 - по Ануфриеву, 1978; 42-44 — самец из заповедника «Кедровая Падь»; 45-46 самец из окрестностей с. Барабаш-Левада, Южное Приморье (типовая местность); 47-58 - пять самцов из Амурской обл. (47-48, 49-50, 51-53, 54-55, и 56-58 - пенис одного самца в разных ракурсах). 
Maritime Territory and 20 males in Amur Area. Both males from the Maritime Territory and 14 males from Amur Area have penis without processes (Figs 42-44, 45-46, and 47-50), 1 male from Amur Area has small underdeveloped processes (Figs 51-53) and 5 males have well developed processes, as on the drawings in the original description (Figs 54-58).

It was impossible to identify two males from the Southern Maritime Territory based on the drawings available; they rather seemed to belong to the new species related to Acia exsultans (McAtee, 1934). Only the collection of numerous materials strictly in the same place in Amur Area allowed ensuring, that the form without penis processes belongs to A. olivacea. The finding of one male with underdeveloped processes in the material from Amur Area provides additional proof of conspecificity of two forms. This is a prominent example of how the discrete variability of genitalia shape could lead to taxonomic error if is left unnoticed.

The shape of penis in species of the genus Acia is rather variable [Dworakowska, 1981]. Moreover, males mutilated by parasitoids are quite common. As a rule, in parasitized specimens pygofer processes are thinner and penis appendages are partially or even fully reduced. Despite the common general trends of genitalia deformation, these changes are individual and different mutilated males have different penis shape [Dworakowska, 1981: p. 5, Figs 39-40 and 43-44].

In $A$. olivacea the situation is reverse. First, the males without penis appendages are far more numerous than males with appendages. Second, variability in both forms is rather small and intermediate variants are rare (only 1 male of 22 in our material). Third, no signs of parasitoids were found on preparations. All this suggests, that in A. olivacea such variability of penis shape is not a result of trauma or a parasitoid invasion.

ACKNOWLEDGEMENTS. I am most grateful to Prof. Georgiy Anufriev (Nizhniy Novgorod) for valuable comments to early drafts of the manuscript and to Nataliya Burlak (Sergiev Posad, Moscow Area) for the help and support during expedition to the Russian Far East.

The study was supported by the Russian State program No. AAAA-A16-116021660095-7 (fieldwork) and Russian Science Foundation, grant No. 14-50-00029 (data handling, preparation of illustrations and manuscript).

\section{References}

Anufriev G.A. 1969. New and little known leaf-hoppers of the subfamily Typhlocybinae from the Soviet Maritime Territory (Homopt., Auchenorrhyncha) // Acta Faun. Ent. Mus. Nat. Pragae. Vol.13. No.153. P.163-190.

Anufriev G.A. 1972. New and little known Palaearctic genera and species Typhlocybinae (Homoptera, Cicadellidae) // Bull. Acad. Polon. Sci., ser. sci. biol. Vol.20. No.1. P. 35-42.

Anufriev G.A. 1978. [Leafhoppers of the Maritime Province (Homoptera, Auchenorrhyncha, Cicadellidae)] // Trudy Vsesoyuznogo Entomologicheskogo Obshchestva. Vol.60. 215 pp. [in Russian].

Anufriev G.A., Emelyanov A.F. 1988. [Suborder Cicadinea (Auchenorrhyncha)] // Opredelitel' nasekomyh Dal'nego Vostoka SSSR. Vol.2. Leningrad: Nauka Publ. P.12-495 [in Russian].

Dworakowska I. 1981. On the genera Acia McAtee and Omia gen. n. (Typhlocybinae, Cicadellidae) // Annot. zool. bot. No.141. P.1-47.

Dworakowska I. 1993. Remarks on Alebra Fieb. and Eastern Hemisphere Alebrini (Auchenorrhyncha: Cicadellidae: Typhlocybinae) // Entomotaxonomia. Vol.15. No.2. P.91-121.

Emeljanov A.F., Tishechkin D.Yu. 2012. Contributions to the study of the genus Reptalus Emeljanov, 1971 (Homoptera: Auchenorrhyncha: Cixiidae) of Western Tien Shan Mountains // Russian Entomol. J. Vol.21. No.3. P.309-314.

Giard M.A. 1889. Sur la castration parasitaire des Typhlocyba par une larve d'Hyménoptère (Aphelopus melaleucus Dalm.) et par une larve de Diptère (Atelenevra spuria Meig.) // Comptes rendus Acad. sci. T.109. No.19. P.708-710.

Gnezdilov V.M. 1999. Variability of the male genitalia structure in Arocephalus languidus (Flor) (Homoptera, Cicadellidae) // Entomologicheskoe Obozrenie. Vol.78. No.3. P.625-628 [in Russian with English summary].

Hamilton K.G.A. 1983. Revision of the Macropsini and Neopsini of the New-World (Rhynchota: Homoptera: Cicadellidae), with notes on intersex morphology // Memoirs of the Entomol. Soc. Canada. Vol.123. P.1-223.

Le Quesne W.J., Woodroffe G.E. 1976. Geographical variation in the genitalia of three species of Cicadellidae (Hemiptera) // Syst. Entomol. Vol.1. P.169-172.

Olmi M. 1976 Variabilita' morfologica di un cicadellide dannoso alle graminacee foraggere negli alti pascoli Piemontesi // Fragmenta Entomologica. Vol.12. Fasc.1. P.103-112.

Ribaut H. 1936. Homoptères Auchénorrhynques. I (Typhlocybidae) // Faune de France. Vol.31. 231 pp.

Tishechkin D.Yu. 2002. Review of species of the genus Laburrus (Homoptera, Cicadellidae) of European Russia//Zoologicheskiy Zhurnal. Vol.81. No.7. P.797-810 [in Russian with English summary]. English translation: Entomological Review. 2002. Vol.82. No.5. P.593-606.

Tishechkin D.Yu. 2015. Taxonomic study of Central Asian species of the genus Macropsis Lewis, 1836 (Homoptera: Auchenorrhyncha: Cicadellidae: Macropsinae). III: Descriptions of two new willow-dwelling species, new synonym, annotated checklist, and key to species // Zootaxa. Vol.3985. No.1. P.31-52.

Wagner W. 1967. Taxonomie der Gattung Paluda De Long, 1937 (Homoptera, Euscelidae) // Zool. Beiträge. Bd.13. S.479-501. 